\title{
PENGARUH CORPORATE SOCIAL RESPONSIBILITY TERHADAP CORPORATE IMAGE PT BANK NEGARA INDONESIA, TBK
}

\author{
Ratih Hurriyati \\ Santi Sofyani
}

\begin{abstract}
ABSTRAK
Industri perbankan di Indonesia mengalami perkembangan yang sangat pesat dari waktu ke waktu. Hal ini menunjukan persaingan yang tinggi, terutama dikarenakan bank-bank asing diperbolehkan membuka cabangnya di Indonesia sehingga produk perbankan yang ditawarkan jauh lebih bervariasi. Bank harus mendapatkan kepercayaan dari masyarakat agar dapat bertahan. Kepercayaan tersebut diperoleh jika bank memiliki citra yang baik karena corporate image yang baik merupakan syarat mutlak keberhasilan suatu bank. Berdasarkan data IMAC 2005 dan 2006 PT Bank Negara Indonesia, Tbk mengalami penurunan peringkat corporate image dan berada pada posisi lebih rendah dari pesaingnya. Pelaksanaan program Corporate Social Responsibility disinyalir menjadi salah satu penyebabnya. Kondisi tersebut telah memicu PT Bank Negara Indonesia,Tbk untuk melakukan berbagai program Corporate Social Responsibility yang lebih dapat dirasakan oleh masyarakat, salah satunya dengan mendirikan gedung sebaguna, rumah asuh, dan sarana olahraga di Desa Margajaya. Oleh karena itu untuk mengetahui kejelasan permasalahan tersebut maka perlu dilakukan penelitian tentang "Pengaruh Corporate Social Responsibility terhadap corporate image PT Bank Negara Indonesia, Tbk".

Penelitian ini dilakukan untuk mengetahui bagaimana Corporate Social Responsibility dan corporate image PT Bank Negara Indonesia, Tbk, dan seberapa besar pengaruh Corporate Social Responsibility terhadap corporate image PT Bank Negara Indonesia,Tbk. Populasi penelitian ini adalah masyarakat Desa Margajaya yang menerima dan mengetahui Corporate Social Responsibility PT Bank Negara Indonesia, Tbk sebanyak seratus orang.

Penelitian ini bersifat deskriptif verifikatif dan menggunakan metode explanatory survey, selain itu berdasarkan kurun waktu, penelitiannya menggunakan metode pengembangan cross sectional methode. Adapun teknik analisa yang digunakan adalah analisis jalur (path analysis) dengan alat bantu software komputer SPSS 10

Berdasarkan hasil pengujian statistik diperoleh temuan terdapat pengaruh yang positif antara Corporate Social Responsibility dengan Corporate Image maka diperoleh kesimpulan bahwa corporate image dipengaruhi oleh Corporate Social Responsibility sebesar 97,67\%, sisanya sebesar 2,33\% dipengaruhi oleh faktor lain.
\end{abstract}

\section{PENDAHULUAN}

Era globalisasi yang penuh dengan tantangan serta perubahan lingkungan internal dan eksternal yang dinamis menuntut perbankan Indonesia untuk dapat bekerja lebih profesional. Peningkatan kualitas ini juga didorong oleh makin tingginya tingkat persaingan dikarenakan bankbank asing diperbolehkan membuka cabangnya di Indonesia sehingga jasa atau produk perbankan yang ditawarkan jauh lebih bervariasi. Hal tersebut berdampak pada penurunan pangsa pasar sepuluh bank terbesar yang terdiri dari Bank Mandiri, BRI, BNI, BCA, Bank Danamon, Bank Niaga, Bank Permata, Bll, Citibank, Bank Panin, sehingga dari sisi aset sampai akhir tahun 2006 tinggal menguasai $61,82 \%$ pangsa pasar, jumlah tersebut menurun apabila dibandingkan dengan tahun sebelumnya yang masih berada pada level $63,85 \%$.

Persaingan yang tinggi dalam industri perbankan saat sekarang ini juga disebabkan karena adanya peraturan pembatasan penjaminan jumlah uang simpanan nasabah yang ditetapkan oleh pemerintah. Lembaga Penjamin Simpanan (LPS) sudah menetapkan sejak bulan Maret tahun 2007 hanya akan menjamin dana simpanan maksimal kurang dari atau sama dengan seratus juta rupiah, lebih dari itu bank harus menjamin sendiri semua dana yang dihimpunnya. Artinya kredibilitas bank sangat mempengaruhi kepercayaan masyarakat. Oleh karena itu, konsumen akan sangat hati-hati dalam memilih bank yang dapat dipercaya. Untuk mempertahankan dan meningkatkan kepercayaan 


\section{StrategiC}

masyarakat, maka bank dituntut untuk memiliki corporate image yang positif.

Bank yang tidak mempunyai citra positif, akan mengalami kesulitan dalam mempertahankan nasabah, karena konsumen akan sangat puas, loyal dan senang menjadi nasabah dari suatu bank yang sehat atau memiliki image positif. Corporate image yang dimiliki suatu bank juga merupakan faktor kunci yang menentukan keberhasilan suatu bank untuk menarik nasabah baru.

Peran corporate image sangatlah mempengaruhi keberhasilan kegiatan suatu lembaga. Rosadi Ruslan (1999:39) mengemukakan bahwa "Citra perusahaan yang baik akan menghasilkan dampak positif yang berkesinambungan bagi seluruh produk dan jasa yang dihasilkan". Hal-hal yang harus dilaksanakan untuk membangun image adalah dengan menciptakan situasi yang logis, selain itu menciptakan diferensiasi dalam pikiran individu diantara serangkaian pesaing yang memiliki visi dan misi yang hampir sama.

Salah satu prestasi corporate image perusahaan di Indonesia yaitu dapat dilihat dari skor Indonesia's Most Admired Companies (IMAC) yang didasarkan pada empat dimensi, yaitu kualitas, kinerja, tanggung jawab, dan daya tarik.

Survei IMAC ini dilaksanakan pada duapuluh tujuh industri antara lain industri makanan dan minuman, toiletries, kosmetik, rokok, ritel, bank nasional dan lain-lain. Prestasi corporate image PT Bank Negara Indonesia, Tbk dapat dilihat pada Tabel 1 di bawah yang berisi skor Indonesia's Most Admired Companies Kategori Bank Nasional.

TABEL 1

IMAC KATEGORI BANK NASIONAL

\begin{tabular}{|l|c|c|c|}
\hline \multirow{2}{*}{ Perusahaan } & \multicolumn{2}{c|}{ Indeks } & Pertumb \\
\cline { 2 - 3 } & $\mathbf{2 0 0 5}$ & $\mathbf{2 0 0 6}$ & uhan \\
\hline $\begin{array}{l}\text { PT Bank Central Asia, } \\
\text { Tbk }\end{array}$ & 3,950 & 3,912 & $-0,038$ \\
\hline PT Bank Mandiri, Tbk & 3,940 & 3,844 & $-0,096$ \\
\hline $\begin{array}{l}\text { PT Bank Negara } \\
\text { Indonesia,Tbk }\end{array}$ & 3,900 & $\mathbf{3 , 7 1 0}$ & $-\mathbf{0 , 1 9 0}$ \\
\hline $\begin{array}{l}\text { PT Bank Rakyat } \\
\text { Indonesia }\end{array}$ & 3,603 & 3,597 & $-0,006$ \\
\hline PT Bank Niaga & 3,465 & 3,514 & 0.049 \\
\hline
\end{tabular}

Sumber: Majalah Marketing 07NI/Juli 2006

Perbandingan hasil IMAC 2006 dan 2005 menunjukan bahwa terjadi penurunan corporate image pada beberapa bank yang termasuk dalam Indonesia's Most Admired Company. PT Bank
Negara Indonesia,Tbk merupakan salah satu bank yang mengalami penurunan indeks Corporate image paling besar, padahal pada tahun 2002 dalam Majalah Marketing edisi September 2002, PT Bank Negara Indonesia,Tbk menjadi juara pertama dalam Indonesia's Most Admired Company tersebut. Data di atas menunjukan pula bahwa corporate image PT Bank Negara Indonesia,Tbk dalam pandangan masyarakat lebih rendah apabila dibandingkan dengan corporate image PT Bank Central Asia Tbk dan PT Bank Mandiri Tbk.

Prioritas utama bagi PT Bank Negara Indonesia,Tbk saat ini adalah berupaya meningkatkan kepercayaan masyarakat terhadap perusahaan sehingga masyarakat tertarik dan tetap loyal menjadi nasabah PT Bank Negara Indonesia,Tbk. Berbagai strategi perlu dilakukan oleh PT Bank Negara Indonesia,Tbk, salah satu tools atau caranya adalah dengan melaksanakan berbagai program Corporate Social Responsibility secara lebih profesional, karena Menurut pendapat Sigit Pramono, Direktur utama PT Bank Negara Indonesia,Tbk dalam majalah Info Bank mengatakan bahwa saat ini faktor responsibility disinyalir mempunyai pengaruh yang cukup besar terhadap turunnya corporate image PT Bank Negara Indonesia,Tbk, karena saat ini PT Bank Negara Indonesia,Tbk telah meningkatkan quality, perpormance, attractiveness, namun pelaksanaan Corporate Social Responsibility PT Bank Negara Indonesia,Tbk meskipun programnya sudah cukup banyak, namun belum merata sampai ke daerah-daerah, selain itu proses pengkomunikasian kegiatan Corporate Social Responsibility oleh PT Bank Negara Indonesia,Tbk belum dilaksanakan secara maksimal, sehingga masyarakat banyak yang tidak mengetahuinya.

Terdapat beberapa penelitian yang menunjukan adanya pengaruh positif Corporate Social Responsibility terhadap corporate image. Salah satunya adalah penelitian yang telah dilaksanakan oleh Bathtacharya dalam Journal of The Marketing yang berjudul The Role of Corporate Social Responsibility in strengthening Multiple Stakeholder Relationship.

Corporate Social Responsibility Efforts such as the Timberland initiative, can create positive associations among consumers that influence the way in which they image with 


\section{StrategiC}

companies (corporate image), and such associations can translate into an array of benefits for companies and nonprofit.

Berkaitan dengan program Corporate Social Responsibility, PT Bank Negara Indonesia,Tbk menyerahkan aktivitas ini sepenuhnya kepada Public Relation yang berada di kantor pusat dan beberapa kantor cabang PT Bank Negara Indonesia,Tbk di berbagai daerah. Corporate Social Responsibility PT Bank Negara Indonesia,Tbk menetapkan fokus utama bantuan non operasionalnya pada sektor pendidikan, kesehatan, keagamaan, dan bantuan bencana. Keempat bidang utama tersebut dipilih dengan pertimbangan atas manfaat langsungnya bagi masyarakat namun tidak membatasi kewajiban PT Bank Negara Indonesia,Tbk pada berbagai proyek lainnya.

Penerapan Corporate Social Responsibility PT Bank Negara Indonesia,Tbk dalam bidang pendidikan antara lain dalam bentuk program beasiswa, perbaikan renovasi bangunan sekolah, pelatihan kepemimpinan serta membangun perangkat pendidikan. Penerapan Corporate Social Responsibility dalam bidang ekonomi dilaksanakan melalui program kemitraan yang memberikan dukungan bagi usaha mikro atau kecil. Program kemitraan PT Bank Negara Indonesia,Tbk ini telah manjalankan kerja sama dengan berbagai perguruan tinggi negeri dan swasta di seluruh Indonesia untuk memfasilitasi penyaluran kredit bagi mahasiswa yang tertarik untuk menjalankan usaha mikro atau kecil. Kontribusi PT Bank Negara Indonesia,Tbk dalam sektor keagamaan mencakup peningkatan kualitas berbagai fasilitas keagamaan dan pemberian sponsor untuk ibadah haji, dalam bidang kemanusiaan yakni melalui program pemberian bantuan kepada para korban bencana alam.

Semua kegiatan sosial tersebut diharapkan dapat meningkatkan kepercayaan masyarakat terhadap aktivitas dan produk PT Bank Negara Indonesia,Tbk yang pada gilirannya akan berpengaruh terhadap meningkatnya intensitas nasabah dalam pemakaian jasa PT Bank Negara Indonesia,Tbk, meningkatkan simpati masyarakat sehingga daya tarik mereka untuk menjadi nasabah PT Bank Negara Indonesia,Tbk juga meningkat.

Mengingat pentingnya perusahaan mengetahui pengaruh Corporate Social
Responsibility terhadap corporate image PT Bank Negara Indonesia,Tbk, maka perlu diadakan penelitian dengan judul: "Pengaruh Corporate Social Responsibility terhadap Corporate Image PT Bank Negara Indonesia,Tbk" (Survei Pada Masyarakat Desa Margajaya, Tanjungsari - Sumedang)".

\section{KERANGKA PEMIKIRAN}

Setiap perusahaan yang bergerak dalam bidang jasa maupun barang, dalam kegiatan operasinya menjalankan beberapa fungsi yaitu sumber daya manusia, keuangan, produksi, dan pemasaran. Apabila suatu perusahaan telah menghasilkan suatu produk, baik barang maupun jasa maka fungsi yang paling berperan di sini adalah fungsi pemasaran dengan tujuan untuk memenuhi kebutuhan konsumen.

Pemasaran merupakan proses perencanaan konsep, harga, promosi, dan pendistribusian ide-ide barang maupun jasa untuk menciptakan pertukaran yang memuaskan individu dan tujuan organisasi. Pemasaran memudahkan proses pertukaran dengan selalu memperhatikan kebutuhan konsumen yaitu dengan menghasilkan produk yang berupa barang atau jasa yang dapat memenuhi kebutuhan konsumen, menawarkan produk dengan harga tertentu, menyediakan saluran distribusi atau tempat untuk menyalurkan produk kepada konsumen dan membuat program promosi untuk mendapatkan perhatian dari konsumen. Elemen produk (product), harga (price), distribusi (place), dan promosi (promotion) dikenal dengan bauran pemasaran.

Sejumlah penelitian menunjukan bahwa penerapan bauran pemasaran 4P (product, price, place, promotion) terlampau sempit untuk bisnis jasa. Hal ini mendorong banyak pakar pemasaran untuk mendefinisikan ulang bauran pemasaran sehingga lebih aplikatif untuk sektor jasa. Oleh karena itu 4P diperluas dan ditambahkan dengan empat unsur lainnya yaitu people, process, physical evidence, dan customer services (Fandy Tjiptono, 2005:31).

Promosi merupakan salah satu bentuk komunikasi yang dilaksanakan oleh perusahaan untuk memperkenalkan serta meningkatkan corporate image. Cara promosi terdiri dari 6 macam yaitu advertising, personal selling, sales 


\section{StrategiC}

promotion, direct marketing, internet marketing, Public Relation (Craven \& Piercy, 2006:339-340).

Produk merupakan bentuk penawaran organisasi jasa yang ditujukan untuk mencapai tujuan organisasi melalui pemuasan kebutuhan dan keinginan pelanggan. Produk yang ditawarkan bank pada umumnya berkaitan dengan aktivitas menyimpan dana seperti tabungan, asuransi, dan deposito, serta menyalurkan dana seperti kredit rumah dan kredit kendaraan. (Fandi Tjiptono, 2005:31)

Atribut produk memberikan keunikan tersendiri pada produk sehingga membedakan produk yang satu dengan produk yang lain. Pemasar dapat memberikan penekanan pada keunggulan atribut produk agar dapat mengendalikan atau mengarahkan konsumen pada saat melakukan pencarian suatu jenis produk, mengevaluasi pengambilan keputusan dalam suatu pembelian konsumen. Hal tersebut sesuai dengan pendapat Eigel (1994:404) yang menyatakan bahwa: "Atribut produk adalah karakteristik atau sifat suatu produk, umumnya mengacu pada karakteristik yang berfungsi sebagai bahan evaluasi selama pengambilan keputusan pembelian konsumen".

Atribut produk ini terdiri dari physical good, features, quality level, accesories, branding, packaging, waranities, product line (Kotler \& Keller, 2006:497). Atribut produk melalui dimensi merek mampu menciptakan citra (image) terhadap suatu perusahaan. Hal ini sesuai dengan pendapat Buchari Alma (2004:148) bahwa merek dapat membuat citra (image) terhadap suatu perusahaan. Salah satu masukan untuk membentuk image ini ialah merek (Buchari Alma, 2004:148)

Public Relations menurut pendapat Fandy Tjiptono (2005:247) adalah bentuk komunikasi yang bertujuan menjalin relasi baik dengan berbagai stakeholder perusahaan melalui publisitas positif, citra korporasi yang bagus, penanganan rumor, peristiwa dan cerita negatif. Alat-alat utama dalam Public Relation menurut pendapat Kotler dan Amstrong (2006:308) terdiri dari publication (publikasi atau publisitas), event (penyusunan program acara), news (menciptakan berita), sponsorship, speeches (pidato), Media Identity (pendekatan bernegosiasi), social activities (tanggung jawab sosial).
Pada uraian selanjutnya, penulis hanya akan membahas salah satu bauran Public Relations yaitu Corporate Social Responsibility, karena hal tersebut merupakan alat utama dari Public Relations yang digunakan PT Bank Negara Indonesia,Tbk untuk meningkatkan corporate image.

Corporate Social Responsibility memiliki kedudukan yang cukup penting dalam dunia Public Relation, karena perusahaan tidak hanya memikirkan keuntungan materi, tetapi juga kepedulian kepada masyarakat, sehingga diharapkan dapat meningkatkan simpati masyarakat. Hal ini sesuai dengan fungsi Public Relation yang berkaitan dengan social marketing.

Mengutip definisi dari word council for suistainable Development, menurut natufe, yang dikutip oleh Yosai Irianta dalam buku Community Relation (2001:9)

"Tanggung jawab sosial adalah komitmen berkelanjutan kalangan bisnis untuk berperilaku etis dan memberikan sumbangan pada pembangunan ekonomi sekaligus memperbaiki mutu hidup angkatan kerja dan keluarganya serta komunitas lokal dan masyarakat secara keseluruhan".

Secara harfiah, Corporate Social Responsibility atau tanggung jawab sosial perusahaan adalah bentuk perhatian kalangan pebisnis (perusahaan) untuk menciptakan kesejahteraan dan kebaikan bagi para pihak luar terkait (external stakeholders). Terdapat 6 (enam) kelompok besar yang membentuk external stakeholders suatu korporat, yakni para pelanggan (customers/consumers), pemasok (suppliers, distributors), lingkungan (environment), masyarakat sekitar (community, society), pesaing (competitors), dan pemerintah (government).

Sejalan dengan konsep Corporate Social Responsibility, maka manajemen perlu menciptakan perimbangan antara kepentingan internal perusahaan dengan eksternal stakeholders. Para pelanggan mengharapkan produk/jasa yang aman (saat digunakan maupun bila salah penggunaan), kejujuran informasi (terkait iklan/promosi dagang), sikap adil (menyangkut pelayanan), dan sebagainya. Bagi para pemasok/distributor, maka perusahaan diharapkan bersikap adil (transaksi dan kontrak), saling menghargai (mutual respect), jujur dalam berbagi 
informasi, pembayaran tepat waktu (timely payment). Dipandang dari aspek lingkungan hidup, maka perusahaan wajib menjaga kelestarian lingkungan, tidak sembarangan membuang limbah, serta meningkatkan baku mutu lingkungan.

Program-program Corporate Social Responsibility perlu diorganisir dan dikelola dengan hati-hati agar suatu perusahaan dapat bertanggung jawab sosial sesuai dengan pendekatan tanggapan sosial seutuhnya. Menurut pendapat Kotler and Lee (Corporate Social Responsibility:141), terdapat 8 proses dalam mengembangkan suatu program Corporate Social Responsibility, yaitu:

1. Conduct a situation analysis, pada tahap ini perusahaan harus menganalisis situasi eksternal maupun internal, Hal tersebut dapat dilakukan melalui analisis SWOT. Intinya pelaksanaan program Corporate Social Responsibility harus disesuaikan dengan situasi faktual perusahaan.

2. Select target audiences, pada tahap ini perusahaan harus cerdas menetapkan sasaran dari program Corporate Social Responsibility yang akan dilaksanakan, ketidaktepatan menentukan sasaran, hanya akan menjadikan Corporate Social Responsibility sebagai cost centre.

3. Set behavior objectives, setelah sasaran ditetapkan, baru kemudian menentukan tujuan jangka panjang dan jangka pendek dari program Corporate Social Responsibility yang akan dilaksanakan.

4. Determine bariers and motivations to behavior change, perusahaan menganalisa manfaat dan resiko yang akan didapatkan berdasarkan tujuan program Corporate Social Responsibility yang sudah direncanakan tersebut.

5. Develop the marketing mix yang terdiri dari product, price, place, promotion, pada tahap ini, ditetapkan secara lebih nyata mengenai bentuk program, promosi program yang akan dijalankan, biaya yang akan dikeluarkan oleh penerima program, pendistribusian program.

6. Develop a plan for evaluation and monitoring, pada tahap ini ditetapkan bentuk serta waktu evaluasi dan pengawasan program coprorate social responsibility.

7. Establish budget and find funding sources, menetapkan sumber dana dan jumlah dana yang akan dikeluarkan untuk membiayai program Corporate Social Responsibility. Tahap ini sangat mempengaruhi kualitas dan kuantitas program Corporate Social Responsibility.

8. Complete an implementatioan plan, pengimplementasian program Corporate Social Responsibility.

Menerapkan Corporate Social Responsibility merupakan investasi yang baik untuk pertumbuhan dan keberlanjutan bisnis suatu perusahaan. Corporate Social Responsibility dapat diimplementasikan oleh Public Relation masingmasing perusahaan. Menciptakan kegiatan perusahaan yang berkelanjutan merupakan salah satu peran Public Relation terutama membantu menjaga corporate image agar tetap positif.

Kumpulan citra di benak khalayak atau publik membentuk corporate image. Corporate image mencerminkan suatu persepsi publik mengenai tindakan-tindakan masa lampau dan akan menjadi prospek perusahaan di masa mendatang yang menjelaskan pendekatan perusahaan secara keseluruhan dari pihak-pihak terkait (stakeholder) ketika dibandingkan dengan perusahaan lain yang terkemuka (Fombrun, 1996 : 72).

Perusahaan percaya bahwa para pelanggan akan semakin menanti tanda-tanda kewargaan perusahaan yang baik yaitu lebih dari sekedar memasok manfaat rasional dan emosional. Perusahaan yang memandang pemasaran peduli masyarakat yang diimplementasikan pada pelaksanaan Corporate Social Responsibility sebagai peluang bagi mereka untuk meningkatkan corporate image, menaikan pengenalan merek, meningkatkan kesetiaan pelanggan, membangun penjualan, dan menaikan liputan pers (Kotler 2005:31).

Oleh karena itu setiap perusahaan termasuk PT Bank Negara Indonesia,Tbk, harus selalu berusaha meningkatkan citranya. Adapun unsurunsur citra perusahaan menurut pendapat Shirley Harison dalam Marketers Guide To Public Relation, New York: John Willy and Son, yaitu:

1. Personality, keseluruhan karakteristik perusahaan yang dipahami oleh lingkungan di luar perusahaan.

2. Reputation, keyakinan seseorang terhadap perusahaan berdasarkan pengalaman pribadi 


\section{StrategiC}

atau orang lain atas produk atau jasa perusahaan.

3. Values/Ethics, nilai-nilai dan filosofi yang dianut perusahaan, keramahan pelayanan, gaya kerja, dan komunikasi baik internal perusahaan maupun interaksi dengan fihak luar.

4. Corporate Identity, identitas dalam nama, simbol, logo, warna, dan ritual untuk memunculkan perusahaan, merek, dan kepentingan perusahaan.

Berdasarkan penjelasan kerangka berfikir diatas, maka penulis menggambarkan paradigma penelitian sebagai berikut :

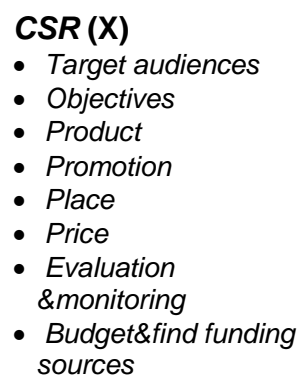

- Objectives

- Product

- Promotion

- Place

- Price

- Evaluation

\&monitoring

- Budget\&find funding sources

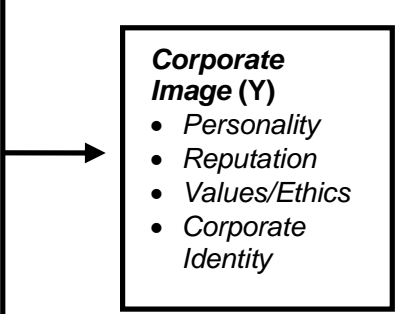

\section{GAMBAR 1 \\ PARADIGMA PENELITIAN}

Keterangan:

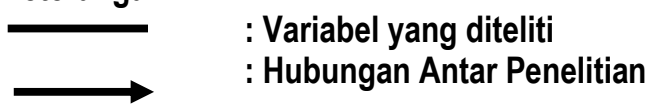

\section{METODE PENELITIAN}

jenis penelitian ini adalah penelitian deskriptif dan verifikatif bertujuan untuk memperoleh deskripsi atau gambaran mengenai program Corporate Social Responsibility dan bagaimana tanggapan masyarakat terhadap corporate image (citra perusahaan) PT Bank Negara Indonesia,Tbk di Desa Margajaya, Tanjungsari-Sumedang.

Adapun verifikatif pada dasarnya ingin menguji kebenaran dari suatu hipotesis yang dilaksanakan melalui pengumpulan data di lapangan, dalam penelitian ini diuji mengenai pengaruh Corporate Social Responsibility terhadap corporate image PT Bank Negara Indonesia,Tbk.

Oleh karena itu, metode penelitian yang digunakan adalah metode survei yang menggunakan kuesioner sebagai alat utama dalam pengumpulan datanya. Ukuran sampel adalah 100 kepala keluarga yang ada di Desa Margajaya, Tanjungsari-Sumedang. Penelitian ini menggunakan teknik cluster random sampling, dikarenakan populasi berdasarkan wilayah tertentu.

Variabel yang dikaji dalam penelitian ini meliputi variabel bebas (independent variabel) yaitu Corporate Social Responsibility (X) yang terdiri dari Target Audience (X1) Objectives and Goals (X2), Product (X3), Promotion (X4), Place (X5), Price (X6), Evaluation and Monitoring (X7), Budget and find finding (X8) sedangkan variabel terikat (dependent variabel) yaitu corporate image (Y) yang terdiri dari personality (Y1), reputation (Y2), values/ethics (Y3), corporate identity (Y4) yang dilaksanakan PT Bank Negara Indonesia,Tbk. Secara lebih lengkap operasionalisasi dari penelitian ini adalah sebagai berikut.

TABEL 3.1

OPERASIONALISASI VARIABEL

\begin{tabular}{|c|c|c|}
\hline $\begin{array}{c}\text { Variabel/Sub } \\
\text { Variabel }\end{array}$ & Indikator & Ukuran \\
\hline $\begin{array}{l}\text { Variabel X } \\
\text { CSR }\end{array}$ & & \\
\hline $\begin{array}{l}\text { Target } \\
\text { Audience }\end{array}$ & $\begin{array}{l}\text { - Ketepatan } \\
\text { pemilihan Desa } \\
\text { Margajaya sebagai } \\
\text { tempat sasaran } \\
\text { - Ketepatan } \\
\text { pemilihan siswa } \\
\text { dan masyarakat } \\
\text { sebagai sasaran } \\
\text { Corporate Social } \\
\text { Responsibility PT } \\
\text { Bank Negara } \\
\text { Indonesia,Tbk }\end{array}$ & $\begin{array}{l}\text { - Tingkat ketepatan pemilihan } \\
\text { Ds Margajaya sebagai tempat } \\
\text { sasaran } \\
\text { - Tingkat Ketepatan pemilihan } \\
\text { siswa dan masyarakat } \\
\text { sebagai sasaran Corporate } \\
\text { Social Responsibility PT Bank } \\
\text { Negara Indonesia,Tbk }\end{array}$ \\
\hline $\begin{array}{l}\text { Objectives } \\
\text { and Goals }\end{array}$ & $\begin{array}{ll}\text { Kesesuaian } & \\
\text { pelaksanaan } & \text { bantuan } \\
\text { dengan } & \text { harapan } \\
\text { masyarakat } & \end{array}$ & $\begin{array}{l}\text { - Tingkat kesesuaian pendirian } \\
\text { panti asuhan dengan } \\
\text { kesejahteraan anak yatim } \\
\text { - Tingkat kesesuaian pendirian } \\
\text { pusat kegiatan olahraga }\end{array}$ \\
\hline Product & 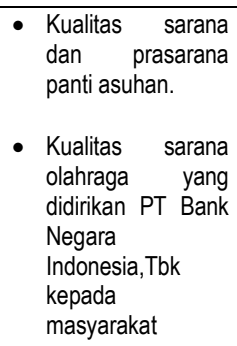 & $\begin{array}{l}\text { - } \text { Tingkat kualitas sarana dan } \\
\text { prasarana panti asuhan } \\
\text { - Tingkat kualitas sarana } \\
\text { olahraga yang didirikan PT } \\
\text { Bank Negara Indonesia,Tbk } \\
\text { kepada masyarakat }\end{array}$ \\
\hline Promotion & $\begin{array}{l}\text { - Kelengkapan } \\
\text { informasi program } \\
\text { Corporate Social }\end{array}$ & 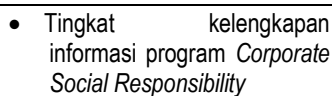 \\
\hline
\end{tabular}

$68-75$ 


\section{StrategiC}

\begin{tabular}{|c|c|c|}
\hline & $\begin{array}{l}\text { Responsibility. } \\
\text { - Daya tarik } \\
\text { informasi } \\
\text { Corporate Social } \\
\text { Responsibility } \\
\text { yang dilakukan } \\
\text { oleh perusahaan } \\
\end{array}$ & $\begin{array}{l}\text { - Tingkat Daya tarik informasi } \\
\text { program Corporate Social } \\
\text { Responsibility yang dilakukan } \\
\text { oleh perusahaan }\end{array}$ \\
\hline Place & 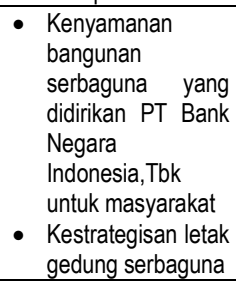 & \begin{tabular}{llr} 
- & Tingkat & \multicolumn{2}{c}{ kenyamanan } \\
bangunan serbaguna yang \\
didirikan PT Bank Negara \\
Indonesia,Tbk \\
masyarakat \\
- $\begin{array}{l}\text { Tingkat kestrategisan letak } \\
\text { gedung serba guna }\end{array}$
\end{tabular} \\
\hline Price & 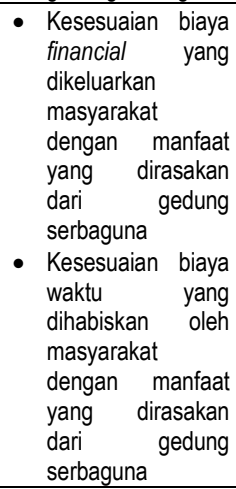 & $\begin{array}{l}\text { - Tingkat kesesuaian biaya } \\
\text { financial yang dikeluarkan } \\
\text { masyarakat dengan manfaat } \\
\text { yang dirasakan dari gedung } \\
\text { serbaguna } \\
\text { - Tingkat kesesuaian biaya } \\
\text { waktu yang dihabiskan oleh } \\
\text { masyarakat dengan manfaat } \\
\text { yang dirasakan dari gedung } \\
\text { serbaguna }\end{array}$ \\
\hline $\begin{array}{l}\text { Evaluation } \\
\text { and } \\
\text { Monitoring }\end{array}$ & $\begin{array}{l}\text { - Perubahan } \\
\text { frekuensi } \\
\text { pemanfaatan } \\
\text { program Corporate } \\
\text { Social } \\
\text { Responsibility } \\
\text { setelah adanya } \\
\text { evaluasi } \\
\text { manajemen } \\
\text { - Perubahan } \\
\text { frekuensi } \\
\text { pemanfaatan } \\
\text { program Corporate } \\
\text { Social } \\
\text { Responsibility } \\
\text { setelah diadakan } \\
\text { pengawasan } \\
\text { pelaksanaan } \\
\text { program Corporate } \\
\text { Social } \\
\text { Responsibility }\end{array}$ & 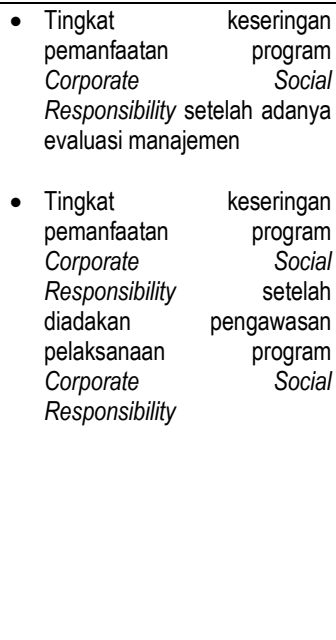 \\
\hline $\begin{array}{l}\text { Budget and } \\
\text { find finding }\end{array}$ & 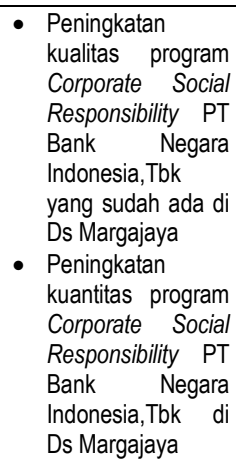 & $\begin{array}{l}\text { - } \text { Tingkat peningkatan kualitas } \\
\text { program Corporate Social } \\
\text { Responsibility PT Bank } \\
\text { Negara Indonesia,Tbk di } \\
\text { Desa Margajaya } \\
\text { - Tingkat peningkatan kuantitas } \\
\text { program Corporate Social } \\
\text { Responsibility PT Bank } \\
\text { Negara Indonesia,Tbk di } \\
\text { Desa Margajaya }\end{array}$ \\
\hline
\end{tabular}

\begin{tabular}{|c|c|c|}
\hline $\begin{array}{l}\text { Variabel Y } \\
\text { Corporate } \\
\text { Image }\end{array}$ & & \\
\hline Personality & $\begin{array}{ll}\text { - } & \text { Kredibilitas } \\
& \text { perusahaan } \\
\text { - } & \text { Keterkenalan } \\
& \text { Perusahaan } \\
\text { - } & \text { Prestasi Corporate } \\
\text { Social } \\
\text { Responsibility } \\
\text { perusahaan } \\
\end{array}$ & $\begin{array}{ll}\text { - } & \text { Tingkat } \\
\text { perusahaan } & \\
\text { - } & \text { Tingkat } \\
\text { Perusahaan } & \text { Keterkenalan } \\
\text { - Tingkat Prestasi Corporate } \\
\text { Social } \\
\text { perusahaan }\end{array}$ \\
\hline Reputation & $\begin{array}{l}\text { - } \text { Kemampuan } \\
\text { perusahaan } \\
\text { mengkomunikasika } \\
\mathrm{n} \text { program } \\
\text { Corporate Social } \\
\text { Responsibility } \\
\text { - Kebanggaan } \\
\text { masyarakat } \\
\text { menjadi nasabah }\end{array}$ & 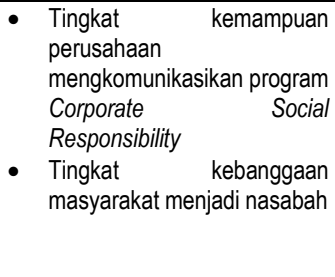 \\
\hline $\begin{array}{l}\text { Values/ } \\
\text { Ethics }\end{array}$ & $\begin{array}{l}\text { - Keramahan antara } \\
\text { personel BNI } 46 \\
\text { dengan } \\
\text { masyarakat }\end{array}$ & $\begin{array}{l}\text { - Tingkat keramahan antara } \\
\text { personel BNI } 46 \text { dengan } \\
\text { masyarakat }\end{array}$ \\
\hline $\begin{array}{l}\text { Corporate } \\
\text { Identity }\end{array}$ & 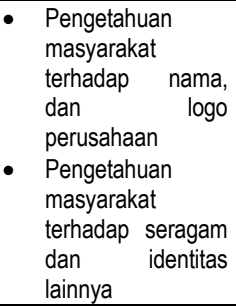 & $\begin{array}{l}\text { - Tingkat pengetahuan } \\
\text { masyarakat terhadap nama, } \\
\text { dan logo perusahaan } \\
\text { - Tingkat pengetahuan } \\
\text { masyarakat terhadap seragam } \\
\text { dan identitas lainnya. }\end{array}$ \\
\hline
\end{tabular}

Sumber: Berdasarkan Hasil Pengolahan Data

dan Referensi Buku

HASIL DAN PEMBAHASAN HIPOTESIS

Pembahasan Tanggapan Responden Mengenai CSR PT BNI, TBK

Corporate Social Responsibility adalah komitmen dunia usaha untuk terus menerus bertindak secara etis, beroperasi secara legal, dan berkontribusi untuk peningkatan ekonomi bersamaan dengan peningkatan kualitas hidup dari karyawan dan keluarganya sekaligus juga peningkatan kualitas komunitas lokal dan masyarakat secara lebih luas. Dalam indikator target audience fokus utama penelitian yaitu ketepatan pemilihan sasaran. Menentukan target audiences merupakan tujuan utama sasaran dalam sebuah program. Target audiences dalam penelitian ini akan membahas ketepatan pemilihan Desa Margajaya sebagai tempat sasaran dan 
ketepatan pemilihan siswa-siswi penerima beasiswa pendidikan.

Dimensi object yang diteliti terfokus pada sejauh mana kesesuaian tujuan yang ditetapkan perusahaan untuk program Corporate social Responsibility (CSR) dengan manfaat yang saat ini dirasakan. Object dalam penelitian ini adalah manfaat adanya rumah asuh dan sarana olahraga, dimensi product yang dimaksudkan disini adalah kualitas dan kuantitas program Corporate Social Responsibility PT Bank Negara Indonesia,Tbk. Dalam penelitian ini akan dibahas mengenai kualitas dan kuantitas sarana rumah asuh Bening Nurani dan sarana olahraga.

Promosi merupakan salah satu alat untuk meningkatkan daya tarik khalayak sasaran yang akan dijadikan subjek kegiatan, sehingga daya tarik tersebut merupakan alat bujukan supaya khalayak dapat mengikuti kegiatan yang sudah direncanakan tersebut. (Kotler dan Amstrong, 2003:79). Promosi kegiatan Corporate Social Responsibility PT Bank Negara Indonesia, Tbk di Desa Margajaya dilakukan melalui word of mouth, spanduk, informasi dari pihak RT adapun promotion pada penelitian ini meliputi kelengkapan dan daya tarik informasi program Corporate Social Responsibility.

Dimensi place merupakan tempat aktivitas perusahaan untuk menyediakan produk bagi khalayak sasaran (Kotler dan Amstrong, 2003:79). Produk tersebut yakni gedung serbaguna, sarana olahraga, sarana pendidikan dan keagamaan, dalam penelitian ini akan dibahas mengenai kenyamanan gedung serbaguna dan kestrategisan letak gedung serbaguna. Dimensi price (harga) merupakan sesuatu pengorbanan yang harus dikeluarkan oleh khalayak untuk memperoleh manfaat adanya gedung serbaguna, sarana dan prasarana olahraga (lapangan voley, basket, tenis meja, bulu tangkis, dan sepak bola), sarana dan prasarana keagamaan, perpustakaan, laboratorium komputer, dan sebagainya. Dalam penelitian ini akan dibahas mengenai kesesuaian antara pengorbanan yang dikeluarkan dengan manfaat yang dirasakan dari program Corporate Social Responsibility.

Dimensi evaluasi harus didasarkan pada pengukuran adanya perubahan perilaku, menyediakan suatu hasil yang riil, pada penelitian ini akan dibahas mengenai evaluasi manajemen dan pengawasan program Corporate Social
Responsibility PT Bank Negara Indonesia,Tbk. Anggaran dan pendanaan merupakan peluang untuk merencanakan kegiatan yang akan diadakan kembali dalam program Corporate Social Responsibility tersebut, apabila terdapat ide-ide program kepedulian sosial lainnya maka tidak terlepas dari dana yang akan dikeluarkan, dan dana tersebut akan sangat berperanan untuk meningkatkan kualitas dan kuantitas program Corporate Social Responsibility PT Bank Negara Indonesia,Tbk. Dana atau anggaran yang dikeluarkan dari suatu kegiatan dapat diperoleh dengan bekerjasama dengan berbagai perusahaan seperti para agen, organisasi yang tidak mencari keuntungan, lembaga sosial, dll. (Kotler dan lee, 2005:142).

Dari hasil pengujian indikator-indikator tersebut dalam kuesioner, diperoleh hasil sebagai berikut:

1 Sebagian besar responden menyatakan bahwa PT Bank Negara Indonesia,Tbk kurang transparance dalam proses pemilihan penerima beasiswa pendidikan, termasuk recruitment anak-anak yang tinggal di rumah asuh. Masayarakat masih merasa ragu dan menganggap tingkat kejujuran pada seleksinya masih dianggap rendah

2 Sebagian besar responden menganggap pemilihan Desa Margajaya, sebagai tempat dilaksanakannya program coprorate social responsibility sudah tepat, masyarakat merespons positif untuk meningkatkan bantuan dari PT Bank Negara Indonesia,Tbk terutama sarana olahraga dan gedung serbaguna.

3 Sebagian besar responden menyatakan raguragu untuk meningkatkan manfaat pendirian rumah asuh, hal itu dikarenakan responden tidak mengetahui secara pasti keadaan di dalam rumah asuh, alasan lain yaitu semakin berkurangnya jumlah anak yang tinggal di rumah asuh tersebut.

4 Sebagian besar responden menyatakan manfaat sarana olahraga yang dirasakan oleh masyarakat sudah sesuai dengan tujuan program Corporate Social Responsibility yang telah ditetapkan sehingga dapat meningkatkan citra perusahaan. Hal tersebut sesuai dengan pendapat Dyah Hasto Palupi 


\section{StrategiC}

dalam Jurnal Kajian Bisnis CSR Isu dan Imlementasinya:

Salah satu langkah yang harus diterapkan dalam melaksanakan CSR adalah CBBO (Cause Business Brand Objective Analysis), menjalankan sebuah program CSR tidak cukup hanya menghadirkan sebuah program social tanpa adanya analisa secara mendalam untuk meningkatkan kesesuaian program tersebut dengan misi dan tujuan perusahaan, apabila CSR dijalankan sesuai dengan business and corporate mission, maka konsumen dan masyarakat juga akan semakin percaya dengan citra perusahaan yang diciptakan selama ini.

5 Sebagian besar responden menyatakan raguragu untuk meningkatkan kualitas rumah asuh yang didirikan oleh PT Bank Negara Indonesia,Tbk, karena responden jarang melihat kondisi rumah asuh tersebut.

6 Sebagian besar responden menyatakan bahwa sarana dan prasarana olahraga yang diberikan oleh PT Bank Negara Indonesia,Tbk berkualitas sehingga dapat mneingkatkan corporate image, hal tersebut sesuai dengan Peranan product CSR untuk meningkatkan corporate image sesuai dengan pendapat Harry Miarsono (GM External Affairs dan Sustainable Development PT Kaltim Prima Coal yang mengatakan bahwa perbaikan kuantitatif dan kualitatif yang diakibatkan oleh sebuah program CSR adalah parameter keberhasilan program CSR dan dapat meningkatkan citra suatu perusahaan).

7 Sebagian besar responden menyatakan bahwa informasi program Corporate Social Responsibility melalui spanduk dan aparat desa sudah lengkap dan berperanan positif untuk meningkatkan corporate image PT Bank Negara Indonesia, Tbk, hal ini sesuai dengan pendapat Agung Nurmansyah (dalam Jurnal Kajian Bisnis VOL 14 No 1 Januari-April 2006), sebagai berikut:

8 Program komunikasi merupakan program yang sangat penting dalam menciptakan pengertian, pemahaman, apresiasi, dan dukungan masyarakat untuk meningkatkan perusahaan sehingga dapat meningkatkan citranya dalam pandangan masyarakat.
9 Sebagian besar responden menyatakan raguragu untuk meningkatkan daya tarik promosi program, karena sebagian besar dari mereka memanfaatkan program Corporate Social Responsibility bukan karena tertarik untuk meningkatkan promosinya.

10 Sebagian besar responden menyatakan gedung serbaguna nyaman untuk digunakan

11 Sebagian besar responden menyatakan raguragu untuk meningkatkan kestrategisan lokasi gedung serbaguna yang berada di Kp Bojong, tempatnya memang nyaman dan jauh dari keramaian, tetapi jaraknya jauh dan tidak ada alat transportasi untuk pulang.

12 Sebagian besar responden menyatakan bahwa ongkos yang dikeluarkan untuk bisa menggunakan program Corporate Social Responsibility PT Bank Negara Indonesia,Tbk sesuai dengan manfaat yang dirasakan

13 Sebagian besar responden menyatakan bahwa tidak sia-sia mereka meluangkan waktu untuk bisa memanfaatkan program Corporate Social Responsibility di Desa Tanjungsari

14 Sebagian besar responden semakin sering memanfaatkan program Corporate Social Responsibility setelah ada evaluasi manajemen dan pengawasan, hal tersebut berdampak pada corporate image sesuai dengan pendapat Miranti abidin, Presiden Direktur Fortune PR yang mengatakan bahwa keberhasilan evaluasi program CSR dapat dilihat pada perubahan perilaku masyarakat untuk meningkatkan program CSR dan berperanan untuk meningkatkan citra perusahaan yang menjalankannya

15 Sebagian besar responden menyatakan bahwa program corporate social responsibility yang diadakan di Desa Margajaya, Tanjungsari telah mengalami peningkatan baik kualitas maupun kuantitas.

\section{Pembahasan Tanggapan Responden Mengenai Corporate Image PT BNI, TBK}

Corporate Image (Citra perusahaan) adalah kesan dari sebuah organisasi yang didasarkan atas pengetahuan dan pengalaman. Pembahasan mengenai corporate image terbagi atas personality, reputation, value/ethics, corporate identity. Jika dimensi-dimensi tersebut baik maka 


\section{StrategiC}

dapat dikatakan bahwa image perusahaan tersebut baik. Oleh karena itu PT Bank Negara Indonesia,Tbk berusaha untuk meningkatkan dimensi-dimensi Corporate Image tersebut untuk mendapatkan Corporate Image yang baik.

1 Indikator pertama adalah personality merupakan hal yang penting untuk deketahui karena menggambarkan keseluruhan karakteristik perusahaan yang dipahami oleh lingkungan di luar perusahaan.

2 Indikator reputation merupakan indikator yang penting dalam variabel corporate image karena menggambarkan keyakinan seseorang untuk meningkatkan perusahaan berdasarkan pengalaman pribadi atau orang lain atas porduk/jasa perusahaan.

3 Value/ethics merupakan indikator dalam corporate image yang benggambarkan tentang pendapat masyarakat untuk meningkatkan nilai-nilai sikap personil, dan budaya perusahaan.

4 Corporate identity merupakan indikator yang sangat penting dalam corporate image karena menggambarkan pengetahuan responden untuk meningkatkan identitas perusahaan dalam nama, simbol, logo, warna dan ritual untuk memunculkan perusahaan, merek, dan kepentingan perusahaan.

Pada dasarnya masing-masing responden memiliki pendapat sendiri mengenai Corporate image PT Bank Negara Indonesia,Tbk. Dari hasil pengajuan indikator-indikator tersebut dalam kuesioner, diperoleh hasil sebagai berikut:

1 Sebagian besar responden menyatakan bahwa mereka ragu-ragu untuk meningkatkan kinerja PT Bank Negara Indonesia,Tbk pada tahun sekarang ini karena dinilai masih rendah dibandingkan bank lain yang cabangnya sudah ada di Kec. Tanjungsari.

2 Sebagian besar responden menyatakan bahwa mereka sangat percaya bahwa PT Bank Negara Indonesia,Tbk merupakan salah satu bank nasional yang terkenal.

3 Sebagian besar responden menyatakan keraguannya untuk meningkatkan prestasi PT Bank Negara Indonesia,Tbk dalam mengimplementasikan program Corporate Social Responsibility.

4 Sebagian besar responden menyatakan bahwa mereka ragu-ragu untuk meningkatkan kinerja public relation PT Bank Negara
Indonesia, hal tersebut dapat dilihat dari beberapa program Corporate Social Responsibility yang dihadirkan tanpa dimusyawarahkan dengan lingkungan sekiitar.

5 Sebagian besar responden akan merasa bangga jika menjadi nasabah dari PT Bank Negara Indonesia,Tbk.

6 Sebagian besar responden menyatakan bahwa personel PT Bank Negara Indonesia, khususnya yang bertugas di YABNI memiliki sikap yang ramah dalam melayani masyarakat.

7 Sebagian besar responden menyatakan bahwa mereka sudah sangat mengenal logo, lambang,dan warna perusahaan.

8 Sebagian besar responden menyatakan bahwa mereka mengenal seragam karyawan PT Bank Negara Indonesia,Tbk.

\section{KESIMPULAN}

Berdasarkan hasil penelitian yang dilakukan oleh peneliti melalui analisis deskriptif dan verifikatif dengan menggunakan path analysis, maka berdasarkan penelitian tersebut dapat diambil kesimpulan sebagai berikut:

1. Tanggapan responden terhadap pelaksanaan corporate social responsibility secara umum sudah cukup baik (Bab IV Hal 185), persepsi responden terhadap corporate social responsibility pada dimensi budget and find finding ditinjau dari penambahan kuantitas program corporate social responsibility yang belum ada, merupakan dimensi yang paling tinggi mendapatkan skor. Penambahan kuantitas program merupakan satu bentuk tanggung jawab sosial kepada masyarakat, karena hal tersebut dapat membahagiakan mereka. Sedangkan perolehan hasil pada dimensi places yang ditinjau dari kestrategisan tempat, mendapatkan skor yang paling rendah dari dimensi-dimensi lainnya, hal ini dikarenakan pemilihan letak gedung yang kurang strategis, karena masih terbatasnya alat transportasi yang melewatinya.

2. Tanggapan responden terhadap corporate image yang terdiri dari personality, reputation, ethics atau value, dan corporate identity secara umum sudah baik. Persepsi responden terhadap ethics/value merupakan dimensi yang memperoleh skor yang lebih 


\section{StrategiC}

tinggi (Hal 168-180). Keramahan pelayanan yang diberikan oleh para personel yayasan Bening Nurani mencerminkan karakter PT Bank Nasional Indonesia,Tbk yang terkenal karena selalu memberikan pelayanan yang terbaik (Hal 177). Sedangkan persepsi responden terhadap personality ditinjau dari kredibilitas perusahaan, mendapatkan skor yang paling rendah dari dimensi-dimensi lainnya, hal ini dikarenakan banyaknya kasuskasus negatif yang pernah terjadi pada PT Bank Negara Indonesia,Tbk yang pada akhirnya berdampak pada persepsi responden terhadap kredibilitas.

3. Corporate Social Responsibility berpengaruh secara positif terhadap Corporate Image. Sehingga setiap praktik bisnis yang dibentuk dengan perencanaan yang baik dalam perwujudan tanggung jawab sosial akan memberikan persepsi yang baik bagi corporate image.

\section{DAFTAR PUSTAKA}

Aaker, David A. (2004). Marketing Research $8^{\text {th }}$ Edition, USA New Jersey, John Willey \& Sons Inc

Ahmad, Rahim, (2002). Awareness of the Concept of CSR among Malaysian Managers in Selected Public listed Companies, Internet Publication of Working Paper Series of International Islamic University Malaysia: Malaysia.

Alifahmi, Hifni. (2005). Sinergi Komunikasi Pemasaran: Integrasi iklan, PR dan Promosi, Jakarta: Quantum

Alma, Bucharl. (2004). Manajemen Pemasaran dan Pemasaran Jasa, Bandung: CV Alfabeta

Anderson, Vince. (2000). Strategic Marketing Management, USA, New York: Houghton Miflin Company

Arikunto, Suharsimi. (2004). Prosedur Penelitian, Jakarta: Penerbit Rineka Cipta.

Berkowitz. (2000). Marketing, USA, Boston: Mc Graw Hill

Bertens, K. (2000). Pengantar Etika Bisnis (2000). Yogyakarta: Kanisius

Boone, Louis E and David L. Kurtz. (2006). Contemporary Business 2006. USA, Ohio:
South Western, A Divison of Thomson Learning

Cravens, david W \& Nigel F. Piercy (2006). Strategic Marketing $8^{\text {th }}$ Edition USA, New York: Mc Graw -Hill Education

Devenport. (2000). Corporate Citizenship: A Stakeholder Approach for Defining Corporate Social Performance and Identifying Measure for Assesing it, Chicago: Business and Society

Ebert, Ronald J, Griffin, Ricky W.(1995). Business Essentials, New Jersey: Prentice-Hall International Inc

Fombrun, J. Charles.(1996). Reputation (Realizing Value from the Corporate Image), Harvard Business School: USA

Griffin, R.W. dan Elbert, R.J. (2003). Bisnis (ed 3), Jakarta: Prenhallindo

\& Ronald J. Ebert. (2006). Business, 8th Edition. Pearson Internasional Edition, New Jersey: Prentice Hall.

Hair, Joseph F . (2000). Marketing Research. USA, New Jersey: Prentice Hall, Pearson Education Inc.

Hasyir, Abdul Dede.(2002), Perwujudan Peran Akuntan dalam Implementasi Corporate Social Responsibility Sebagai Salah Satu Upaya Untuk Meningkatkan Citra Akuntan, dalam LKTI Kongres IX FAI 2002. Media Akuntansi, No.32, Edisi april 2003.

Hermawan, Asep. (2006). Penelitian Bisnis Paradigma Kualitatif, Jakarta: PT Gramedia Widia Sarana Indonesia.

Hopkins, Michael. J. (2003). The Planetary bargain: CSR Matters, London: Earthschan: United Kingdom

Internasional, Astra. (2003). Astra Green Company Annual Report 2004, Jakarta. Astra Internasional

Iriantara, Yosal. (2004). Community Relations, Konsep dan Aplikasinya, Bandung: Simbiosa Rekatama Media

Jefkins, Frank. (2004). Public Relation, Jakarta: Erlangga

Keraf, Sonny. (1998). Etika Bisnis (tuntutan dan relevansinya), Jogjakarta: Kanisius

Kertajaya, Hermawan. (2002). Marketing Plus Siasat Memenangkan Persaingan Global, Jakarta: PT. Erlangga

Kotler, Philip \& Kevin L. Keller. (2006). Marketing Management, $12^{\text {th }} \quad$ Edition Pearson 
Internasional Edition, New Jersey: Prentice Hall.

dan lee, Nancy. (2005). Corporate Social Responsibility: doing the most good for your company and your cause, John willey \& Sons, Inc., Hoboken: New Jersey

\& Garry Amstrong. (2006). Principles of Marketing, 11th Edition Pearson Internasional Edition, New Jersey: Prentice Hall

- (2005). Manajemen Pemasaran Edisi Kesebelas Jilid 1 (Terjemahan), Jakarta: PT. INDEKS Kelompok Gramedia

(2005). Manajemen Pemasaran

Edisi Kesebelas Jilid 1 (Terjemahan), Jakarta:

PT. INDEKS Kelompok Gramedia

McCarthy, E. Jerome. (1993). Basic Marketing A Management Approach, Boston: Richard D Irwin Inc

McDaniel, Lamb Hair (1999). Essential of Marketing. USA, Ohio: International Thompson Publishing

Natufe, O. Igho.(2001). The Problematic of Sustainable Development and CSR : Policy Implications for The Niger Delta. a Conference Paper Urhobo Historical Society, second Annual Conference. New Jersey

Rasyid, Harun Al. (1994). Teknik Penarikan Sampel dan Penyusunan Skala, Program studi IImu Sosial Bidang Kajian Utama Sosiologi Antropologi Program Pasca Sarjana, Bandung: Universitas Pajajaran

Rudito, Bambang dan Melia Famiola. (2007). Etika Bisnis dan Tanggung Jawab Sosial Perusahaan, Bandung: Rekayasa Sains

Ruslan, Rosady. (2000). Kampanye Public Relations, PT Grafindo Persada: Jakarta

Shimp, Terence. A. (2000). Advertising Promotion. USA, South Carolina: The Dryden Press.

(2003).Periktanan Promosi: Aspek Tambahan Komunikasi Pemasaran Terpadu. (Terjemahan), Jakarta: PT Erlangga

Singaribun, Masri dan Sofyan Efendi. (1995). Metode Penelitian Survei, Jakarta: LP3ES

Sugiyono, (2006). Metode Penelitian Bisnis. Bandung: CV Alfabeta

Sutojo, Siswanto. (2004). Membangin Citra Perusahaan. Jakarta: PT Damar Mulia Pustaka

Sukirno, Sadono. (2004). Pengantar Bisnis, Kencana: Jakarta
Sutisna. (2004). Perilaku Konsumen dan Komunikasi Pemasaran, Rosda Karya: Bandung

Tjiptono, Fandi. (2005). Pemasaran Jasa, Malang: Bayumedia Publishing . (2005). Strategi Pemasaran, Yogyakarta: Andi Offset

Umar, Husein. (2003). Metode Riset Bisnis, Jakarta: Penerbit PT Gramedia Pustaka Utama

Uma Sekaran (2006). Metode Penelitian untuk Bisnis, Jakarta: Salemba 4

Wibisono, Yusuf. (2007). Membedah Konsep dan aplikasi CSR (Corporate Social Responsibility). Surabaya: Fascho Publishing

World Business Council for Sustainable Development. (2000). Meeting Changing Expectations: Corporate Social Responsibility, Geneva, Switzerland: Corporate Social Responsibility, Geneva, Switzerland : Corporate Social Responsibility: making Good Business Sense, Geneva, switzerland

Yazid. (2005). Pemasaran Jasa: Konsep dan Implementasi. Yogyakarta: Ekonisia FE UI.

\section{Jurnal dan Seminar}

Berger, Ida E, Identity, Identification, And Relationship Through Social Alliances, Journal of the Academic of Marketing science Vol 34. No 2

Chun, Rosa dan Gary Davies. The Influence of Corporate Character on Customer and Employes: exploring Similarities and differences, Journal of the Academic of Marketing science Vol 34. No 2.

Cornelissen, Joep, Corporate Image: an audience centred model, Corporate Communication, An International Journal. 2000. Vol 5, No 2

Goezol and Scoubeau. (2003). Corporate Communication: An International Jurnal Volume 8

Harison, Shirley dalam Marketers Guide To Public relation, New York: John Willy and Son

Maignan, Issabel.(2004). Corporate Social Responsibility and Marketing. Journal of the Academy of Marketing Science

Maignan, Ferrel, Past Conceptualizations of CSR, Journal of The Academy of Marketing Science. Winter. 2004. Vol 34. No 2 
Nurmansyah, Agung. (2006). Corporate Social Responsibility: Isu dan Implementasinya, kajian Bisnis Vol. 14, No. 1, Januari-April 2006

Paul S.Busch, Brand Portfolio, Corporate Image, and Reputation: Managing Brand Deletion, Journal of The Academy of Marketing Science. Spring. 2006. Vol 34. No 2

Tom J. Brown, Identity, Intended Image, Construed Image, And Reputation, Journal of The Academy of Marketing Science. Spring. 2006. Vol 34. No 2

\author{
Website Internet \\ www.beritabumi.co.id \\ www.bsr.org \\ www.bni.co.id \\ www.csr.org \\ www.csreroupa.com \\ www.kompas.co.id \\ www.pikiranrakyat.co.id \\ www.republika.co.id \\ www.sampoernafoundation.org \\ www.socialcapitalgateway.org \\ www.wikipedia.org \\ www.worldbank.org
}

Artikel, Majalah, Surat Kabar, dan lainnya

Majalah Infobank Edisi agustus, 2006

Majalah Marketing No. 07/VI/Juli 2006

Majalah Marketing No. 09/V/ September 2005

Majalah SWA 26/XXI/19 Desember -11 Januari 2006

Majalah Warta Ekonomi 